\title{
Judicial cooperation in criminal matters in the Special Administrative Regions of Hong Kong and Macau. Through the lens of "one country, two systems" and the surrender of fugitives to Mainland China
}

\author{
Cooperação judiciária em matéria criminal nas Regiões \\ Administrativas Especiais de Hong Kong e Macau. À luz do "um país, \\ dois sistemas" e da entrega de fugitivos à China Continental
}

\section{Miguel Manero de Lemos ${ }^{1}$}

University of Macau - Macau

manero.miguel@gmail.com

https://orcid.org/0000-0003-3644-2006

\section{Teresa Lancry Robalo ${ }^{2}$}

University of Macau - Macau

teresaso@um.edu.mo

https://orcid.org/0000-0001-5449-063X

\begin{abstract}
This Article proceeds in three parts. Part I (The constitutional systems of the Special Administrative Regions of Hong Kong and Macau) introduces the readers to the historical background of Hong Kong and Macau and the "one country, two systems" constitutional orders in force in the Hong Kong and the Macau Special Administrative Regions of the People's Republic of China. It also informs on the most relevant constitutional developments occurring in the first two decades of existence of these two special regions. Part II (Judicial cooperation in criminal matters in the Special Administrative Regions) explains how such constitutional orders influence the extant legal framework on
\end{abstract}

1 Assistant Professor at the Faculty of Law, University of Macau. Phd in Law, Faculty of Law, University of Coimbra.

2 Assistant Professor at the Faculty of Law, University of Macau. Phd in Law, Faculty of Law, University of Macau. 
judicial cooperation in criminal matters, which applies to external cooperation with other states or territories, but not to cooperation between the different jurisdictions within China, for which there are no positive rules currently in force. This part surveys the rules in force in Hong Kong and Macau concerning the surrender of fugitives to other countries. Part III (The surrender of fugitives to Mainland China) focuses particularly on the issue of arrest and return of Chinese citizens from Hong Kong and Macau to Mainland China. It provides an overview of the cases that came to public attention and the legal conundrums created by the absence of "two systems" specific rules on surrender of fugitives within "one country".

KeYwords: Hong Kong; Macau; Mainland China; Surrender of Fugitives; "One country, two systems".

Resumo: Este artigo divide-se em três partes. A Parte I (O sistema constitucional das Regiões Administrativas Especiais de Hong Kong e Macau) fornece o enquadramento histórico das Regiões Administrativas Especiais de Hong Kong e Macau e introduz as ordens constitucionais das Regiões Administrativas Especiais de Hong Kong e Macau da República Democrática da China existentes à luz do princípio "um país, dois sistemas". É feita uma referência aos principais desenvolvimentos constitucionais ocorridos nas primeiras décadas de existências dessas regiões administrativas especiais. A Parte Il (Cooperação judicial em matéria criminal nas Regiões Administrativas Especiais) explica como é que as referidas ordens constitucionais influenciam o quadro jurídico existente relativo à cooperação judicial em matéria criminal, o qual se aplica à cooperação com outros Estados ou territórios, mas não à cooperação entre as várias jurisdições existentes na China, cooperação esta para a qual não existem regras positivadas atualmente em vigor. Examinam-se as regras em vigor em Hong Kong e em Macau sobre a entrega de fugitivos para outros países. A parte III (A entrega de fugitivos à China continental) lida particularmente com a questão da detenção e entrega de cidadãos chineses de Hong Kong e Macau à China continental. Fornece uma visão geral dos casos vindos a público e do dilema jurídico criado pela falta de regras específicas relativas à entrega de fugitivos dentro do "um país".

Palavras-Chave: Hong Kong; Macau; China Continental; Entrega de Fugitivos; "Um país, dois sistemas".

SUMÁRIO: Introduction; 1 . The constitutional systems of the Special Administrative Regions of Hong Kong and Macau; 2. Judicial cooperation in criminal matters in the Special Administrative Regions; 3 . The surrender of fugitives to Mainland China; Conclusion; References. 


\section{INTRODUCTION}

This Article proceeds in three parts. Part I (The constitutional systems of the Special Administrative Regions of Hong Kong and Macau) introduces the readers to the historical background of Hong Kong and Macau and the "one country, two systems" constitutional orders in force in the Hong Kong and the Macau Special Administrative Regions of the People's Republic of China. It also informs on the most relevant constitutional developments occurring in the first two decades of existence of these two special regions. Part II (Judicial cooperation in criminal matters in the Special Administrative Regions) explains how such constitutional orders influence the extant legal framework on judicial cooperation in criminal matters, which applies to external cooperation with other states or territories, but not to cooperation between the different jurisdictions within China, for which there are no positive rules currently in force. This part surveys the rules in force in Hong Kong and Macau concerning the surrender of fugitives to other countries. Part III (The surrender of fugitives to Mainland China) focuses particularly on the issue of arrest and return of Chinese citizens from Hong Kong and Macau to Mainland China. It provides an overview of the cases that came to public attention and the legal conundrums created by the absence of "two systems" specific rules on surrender of fugitives within "one country".

\section{The constitutional systems of the Special Administrative Regions of Hong Kong and Macau}

The territories of Hong Kong and Macau were for a long time under the "sovereignty" or "exercise of sovereignty" of Great Britain and Portugal, until they were returned to the People's Republic of China (hereinafter, PRC) in 1997 and 1999 respectively $^{3}$.

3 In the Joint Declaration on the Question of Hong Kong, while the PRC declared that it would resume the "exercise of sovereignty" over Hong Kong, the United Kingdom declared it would "restore Hong Kong” to China. Joint Declaration on the Question of Hong Kong, China-UK, Dec. 19, 1984, 1399 U.N.T.S. 23,391, par. 1 and 2. In the Joint Declaration on the Question of Macau, the PRC and Portugal declared that "Macau [...] is Chinese territory". 
In order to ensure the peaceful return of these territories to the "embrace of the motherland" 4 , the PRC concluded two international treaties, branded as Joint Declarations, with the United Kingdom and Portugal. The one most outstanding of commands of these Joint Declarations is, in short, "one country, two systems”. Half a year prior to the signing of the Joint Declaration on the Question of Hong Kong, Deng Xiaoping aptly unveiled the core of the separation of systems embodied in this unprecedented principle: while the one billion people from the Mainland "maintain" the socialist system, Hong Kong "continues" with its own system ${ }^{5}$. According to the twelfth basic policy of the two Joint Declarations,

Joint Declaration on the Question of Macau, China-Port., Mar. 22, 1988, 1498 U.N.T.S. 25, 805, par. 1 (emphasis added).While this clause in the Joint Declaration on the Question of Macau is the natural outcome of the fact that the Portuguese Constitution had for over a decade 'given up' sovereignty over Macau (on the Portuguese control over the territory as a "limited sovereignty", see PEREIRA, Francisco, Portugal, China e a "Questão De Macau", Instituto Português do Oriente, 2nd Edition, p. 41-46), the "co-existence" of two clauses in the Joint Declaration on the question of Hong Kong is "a result of an agreement not to agree”. CHAN, Johannes, From Colony to Special Administrative Region. Law Of The Hong Kong Constitution, edited by CHAN, Johannes SC (Hon) \& LIM, C.L., Hong Kong, Thomson Reuters Hong Kong Limited trading as Sweet \& Maxwell, 2015, p. 24. In fact, while the Portuguese Constitution recognized Macau as merely "under the administration" of Portugal as far back as 1976 (see Article 5 (4) of the Portuguese Constitution of 1976), the United Kingdom emphasized for longer its sovereign rights. The Hong Kong Act of 1985 only provided for the termination of British sovereignty over Hong Kong as from 1 July 1997. On the whole "sovereignty" versus "exercise of sovereignty" issue, see LEMOS, Miguel Manero de, The Basic Laws of Hong Kong and Macau as Internationally Shaped Constitutions of China and the Fall Off of 'One Country, Two Systems', Tulane Journal of International and Comparative Law (Upcoming, March 2019), Part II.

4 Thus, "end[ing] past humiliation and mark[ing] a major step forward toward the complete reunification of China". Chinese President Xi Jinping speech delivered at the meeting celebrating the 20th anniversary of Hong Kong's return to the motherland, 1 July 2017. http://www.xinhuanet.com/ english/2017-07/01/c_136409940.htm.

5 XIAOPING, Deng, One Country, Two Systems, June 22-23, 1984. See Deng Xiaoping's full remarks in https://dengxiaopingworks.wordpress. com/2013/03/08/one-country-two-systems/. For a deeper understanding of how the separation of systems was idealized by Deng Xiaoping see the 
"[twelve comprehensive] basic policies of the People's Republic of China regarding Hong Kong [and Macau] and the elaboration of them in Annex I to [these] Joint Declaration[s] will be stipulated, in [...] Basic Law[s] of the Hong Kong and [the Macau] Special Administrative Region of the People's Republic of China, by the National People's Congress of the People's Republic of China, and they will remain unchanged for 50 years"

Adopted around half a decade later, the Basic Laws of Hong Kong and $\mathrm{Macau}^{7}$, two "creative masterpieces" in the words of Deng, ${ }^{8}$ are, at present, the two constitutional documents that govern the two Special Administrative Regions (hereinafter, SARs) ${ }^{9}$. They are premised upon the notion that "[t]he socialist system and policies shall not be practised in the [...] Special Administrative Region[s], and the previous

whole volume III of the Selected Works of Deng Xiaoping available at https:// dengxiaopingworks.wordpress.com/selected-works-vol-3-1982-1992/.

6 Joint Declaration on the Question of Hong Kong, paragraph 3 (12) and Joint Declaration on the Question of Macau, para 2 (12) (emphasis added).

7 The Basic Laws are titled "Basic Law of the Hong Kong Special Administrative Region of the People's Republic of China" and "Basic Law of the Macau Special Administrative Region of the People's Republic of China".

8 At the end of their task, the drafters of the Basic Law of Hong Kong were superbly complimented by Deng Xiaoping: "you have produced a law that is of historic and international significance. By historic I mean it is significant not only for the past and the present but also for the future. By international and far-reaching I mean it is significant not only for the Third World but for all mankind. This document is a creative masterpiece”. Deng Xiaoping, Impromptu remarks to members of the Drafting Committee for the Basic Law of the Hong Kong Special Administrative Region who were attending its Ninth Plenary Meeting. http://www.chinadaily.com.cn/china/ cpc2011/2010-09/15/content_12474319_5.htm.

9 Arguably, the most authoritative statement and analysis on the nature of the Basic Laws can be found in the Judgment $\mathrm{Ng}$ Ka Ling, where the Court of Final Appeal of Hong Kong considered, while emphasizing the purpose of the Basic Law of implementing the Joint Declaration, that "[t]he Basic Law is an entrenched constitutional instrument to implement the unique principle of 'one country, two systems'”. Ng Ka Ling and Another V. The Director of Immigration [1999] HKCFA (29 January 1999) (hereinafter Ng Ka Ling (1)), par. 73 (emphasis added). 
capitalist system and way of life shall remain unchanged for 50 years" ${ }^{10}$. According to the Basic Laws,

"[the SARs] exercise a high degree of autonomy and enjoy executive, legislative and independent judicial power, including that of final adjudication"11.

Although this high degree of autonomy does not extend to foreign and defence affairs, which lie within the responsibility of the Central People's Government ${ }^{12}$, the Basic Laws, as explained throughout this Article, assign important powers in the domain of external affairs to the SARs.

The Basic Laws were adopted pursuant to Article 31 of the PRC's most prominent constitutional document, the Constitution of the PRC, a socialist constitution. The PRC Constitution presides over the 1.3 billion people of the Mainland and also, possibly, at least in part, over the people of Hong Kong and Macau ${ }^{13}$.

In this tripartite unique constitutional arrangement - where three very different political, legal and judicial traditions coexist within "one country" and where separation encompasses hard-borders, different passports, different freedoms, different currencies, etc. ${ }^{14}$ - political, judicial

10 HKBL, Article 5; MBL, Article 5 (emphasis added).

11 HKBL, Article 2; MBL, Article 2 (emphasis added).

12 HKBL, Articles 13 and 14; MBL, Articles 13 and 14.

13 Views on its applicability, on how such applicability occurs and on which norms of the PRC Constitution are actually applicable in the SARs vary. The "irony" inherent to the question is exemplified by the declaration of the members of the Basic Law Drafting Committee that the PRC Constitution "as a whole is applicable to [the SARs], but it does not mean that all is applicable”. FU H L, Supremacy of a Different Kind: The Constitution, the NPC, and the Hong Kong SAR, Hong Kong's Constitutional Debate, Conflict over Interpretation, CHAN, FU, GHAI (eds), Hong Kong University Press, 2000, p. 100. The general trend is to argue that the provisions of the PRC Constitution on the unity and integrity of the state, powers of the sovereign organs and national symbols apply. According to the first author of this Article, the PRC Constitution was not supposed to apply at all in the SARs. But such is an isolated view. On this, see LEMOS, Miguel Manero de, The Basic Laws of Hong Kong and Macau as Internationally Shaped Constitutions of China and the Fall Off of 'One Country, Two Systems', Tulane Journal of International and Comparative Law (Upcoming, March 2019).

14 For an understanding of the whole SARs' picture see, for example, the different contributions in Law Of The Hong Kong Constitution, edited by CHAN, 
and legal difficulties and tensions are inevitable. The interaction between the Central Authorities and the SARs is defined in the Basic Laws, most prominently in chapters entitled "[r]elationship between the Central Authorities and the [...] Special Administrative Region[s]”, but also in many other provisions that one can find throughout the documents ${ }^{15}$. The "relationship" is not always delineated in a clear way. Such is not due to the carelessness of the drafters of the Basic Laws but to a deliberate ambiguity inherent to the complex 'negotiation' process that led to their adoption ${ }^{16}$. The intense, but at times unsuccessful, attempts to reconcile seemingly irreconcilable perspectives, and the need to attune what was agreed upon in the Joint Declarations with the political realities existing half a decade after these international treaties were concluded, have left no room for clear-cut solutions ${ }^{17}$.

Unsurprisingly, at least in hindsight, tensions at the politicaljudicial level emerged early in the life of the first SAR, the Hong Kong SAR. An example of how difficult it is to reconcile the theoretical and legal separation of systems with reality on the ground, 'irreconcilable' views arose in a judicial case over the right of abode in Hong Kong of children born in Mainland China and whose father or mother had the right of abode in Hong Kong. For present purposes, it suffices to note that the Court of Final Appeal of Hong Kong (hereinafter, HKCFA) upheld such right in terms that were considered perilous by the Government of Hong Kong, namely because it could lead to an influx of roughly 1.6

Johannes SC (Hon) \& LIM, C.L., Hong Kong: Thomson Reuters Hong Kong Limited trading as Sweet \& Maxwell, 2015.

15 Of particularly relevance are the articles on interpretation and amendment of the Basic Laws. HKBL, Articles 158 and 159; MBL, Articles 143 and 144.

16 On the process of drafting of the Basic Law of Hong Kong see, for example, CHAN, Johannes, From Colony to Special Administrative Region, p. 31 and 32. Personal account of the early drafting history, and complexity inherent to the issue of interpretation of the Basic Law, in LEE, Martin, A Tale of Two Articles, The Basic Law and Hong Kong's Future, ed. WESLEY-SMITH, Peter and CHEN, Albert H. Y., Hong Kong: Butterworths, 1988, p. 309-325. On the relatively less problematic process of drafting of the Basic Law of Macau, see PEREIRA, Francisco, Portugal, China e a "Questão de Macau, cit., p. 139-142.

17 On the influence that the Tiananmen incidents of 1989 might have had in the final solutions that were eventually 'agreed upon', see CHAN, Johannes, From Colony to Special Administrative Region, cit., p. 32, p. 1079. 
million people from the Mainland over the period of a decade ${ }^{18}$. In line with such consideration, the Government of Hong Kong decided to ask for the help of the Central Authorities ${ }^{19}$. The Standing Committee of the National People's Congress acceded to the request by issuing an interpretation of the Basic $\mathrm{Law}^{20}$ that reversed de iure and/or de facto the decision of the HKCFA ${ }^{21}$. This interpretation was adopted under, inter alia, ${ }^{22}$ Article 158 of the HKBL, which constitutes a perfect instance of the above mentioned deliberate ambiguity, in that it 'peculiarly shares', in no certain terms, interpretive power between the Central Authorities and the courts in Hong Kong ${ }^{23}$.

The case highlighted not only the physical reality of intense movement of people - and deeply shared bonds of life - between Hong Kong and the Mainland, but also the very different political and judicial

18 https://www.info.gov.hk/gia/general/199905/18/0518159.htm.

19 See The Chief Executive's Report to the State Council Concerning the Right of Abode, 20 May 1999.

20 The Interpretation by the Standing Committee of the National People's Congress of Articles 22(4) and 24(2)(3) of the Basic Law of the Hong Kong Special Administrative Region of the People's Republic of China (Adopted at the Tenth Session of the Standing Committee of the Ninth National People's Congress on 26 June 1999) (hereinafter Interpretation $\mathrm{Ng} \mathrm{Ka} \mathrm{Ling).}$

21 For an extensive discussion of this interpretation, see Hong Kong's Constitutional Debate, Conflict over Interpretation, CHAN, FU, GHAI (eds), Hong Kong University Press, 2000.

22 The Standing Committee stated its interpretative power in the domain of the Basic Law is also grounded on Article 67 (4) PRC Constitution. On the pernicious effects of invoking the socialist provisions of the PRC Constitution in Hong Kong and Macau matters, see LEMOS, Miguel Manero de, Too late for the Standing Committee to take a "good faith" step back? And the possibility of the Court of Final Appeal to save "one country, two systems" by asserting its constitutional power of control over the actions of the Standing Committee, in BIAGI, Francesco, FROSINI, Justin O. and MAZZONE, Jason (eds.), Constitutional History: Comparative Perspectives (Brill forthcoming 2019).

On Article 158, see LING, Bing, Subject Matter Limitation on the NPCSC's Power to Interpret the Basic Law, 37 Hong Kong Law Journal, 2007, arguing that the Standing Committee has no power to interpret provisions of the Basic Law which concern the autonomy of Hong Kong but accepting a proprio motu power of the Standing Committee to interpret other provisions. See also LEMOS, Miguel Manero de, Too late for the Standing Committee to take a "good faith" step back? cit., arguing that no proprio motu power is provided for in the Basic Laws. 
traditions on the two sides of the hard-border. Having interpreted the provisions of the Basic Law at stake in one way and disposed of the case accordingly, the fiercely independent HKCFA even asserted, in Marbury vs Madison mode, its own authority to review the constitutionality of the acts of the most powerful organ of the PRC, the National People's Congress (NPC) ${ }^{24}$. Reaction 'on the Mainland side of the border' was robust ${ }^{25}$ and the standoff with the Central Authorities ended with a kind of silent compromise, according to which the concurrent 'final authority' of the two organs to interpret the Basic Law was upheld, with unspoken prominence assigned to the Standing Committee. Since then, the courts in Hong Kong have adopted a "soft controls" approach in order to avoid another direct confrontation ${ }^{26}$.

Not long after, in 2003, tensions surfaced again at the politicalsocietal level over the question of implementation of a law on national security as constitutionally instructed by Article 23 of the Basic Law, which provides that

"[t]he [...] Special Administrative Region shall enact laws on its own to prohibit any act of treason, secession, sedition, subversion against the Central People's Government, or theft of state secrets, to prohibit foreign political organizations or bodies from conducting

${ }^{24} \mathrm{Ng} \mathrm{Ka}$ Ling (1), par. 64, 65.

25 The Mainland scholarly reaction to the assertion of the HKCFA is one example. See WEIYUN, Xiao and others, Why the Court of Final Appeal Was Wrong: Comments of the Mainland Scholars on the Judgment of the Court of Final Appeal, in Hong Kong's Constitutional Debate, Conflict over Interpretation, CHAN, FU, GHAI (eds), Hong Kong University Press, 2000, p. 55 and 56: "the judgment which said that the CFA could review whether a decision of the NPC Standing Committee was consistent with the Basic Law was patently wrong" (opinion of Xiao Weiyun, emphasis added); the circumstance that the jurisdiction of the CFA is, in nature, that of a sovereign power was considered "ridiculous" (opinion of Shao Tianren).

26 See its efforts to find innovative confront-avoidance devices, for example, in Ng Ka Ling \& Others v. Director of Immigration (No 2), 26 February 1999; HKSAR v. Ng Kung Siu, (1999) 2 HKCFAR 442; Director of Immigration, v. Chong Fung Yuen, [2001] HKCFA 48), See also Benny Tai, 'The Judiciary', in Contemporary Hong Kong Government and Politics, Expanded Second Edition, eds WAI-MAN, Lam, LUI, Percy Luen-tim, Wilson Wong, (Hong Kong University Press, 2012), (n. 86) 77-8. 
political activities in the Region, and to prohibit political organizations or bodies of the Region from establishing ties with foreign political organizations or bodies"27.

Implementation roundly failed ${ }^{28}$ and, in the following year, controversy arose again in relation to constitutional development on the question of universal suffrage ${ }^{29}$, highlighting the different views over the pace of democratization that is desired by many in Hong Kong and the one that is found more adequate by the Central Authorities. In the face of another ambiguous provision of the Basic Law over who has the initiative to start the process for amending the rules for selecting the Chief Executive of the SAR and electing its Legislative Assembly $^{30}$, the Standing Committee issued its second interpretation ${ }^{31}$

\section{Article 23 of the Basic Laws.}

28 Consider the following account in GITTINGS, Danny, Introduction to the Basic Law, Hong Kong Univ. Press 2013, p. 106: “an extreme example of this came during more than 180 hours of scrutiny by the Legislative Council of the National Security (Legislative Provisions) Bill in early 2003. This controversial bill primarily sought to implement the requirement in Article 23 [...]. But it aroused so much opposition during the legislative process that the government was forced to table three revised versions of the bill and 51 amendments, some making major changes to its original proposals. However, all these changes failed to appease the bill's critics. Instead, the highly publicized process of legislative scrutiny arguably only intensified public opposition. As a result, after a massive street protest by more than half a million people on 1 July 2003, legislators who had previously promised to support the bill changed their minds. Lacking enough support in the Legislative Council to secure its enactment, the executive was left with no choice but to withdraw the bill just days before it was due to be put to a vote".

29 According to the Basic Law of Hong Kong the "ultimate aim[s]" are "the selection of the Chief Executive by universal suffrage upon nomination by a broadly representative nominating committee in accordance with democratic procedures" and "the election of all the members of the Legislative Council by universal suffrage". HKBL, Articles 45 and 68.

30 See Annexes I and II of the Basic Laws.

31 The Interpretation by the Standing Committee of the National People's Congress of Article 7 of Annex I and Article III of Annex II to the Basic Law of the Hong Kong Special Administrative Region of the People's Republic of China (Adopted at the Eighth Session of the Standing Committee of the Tenth National People's Congress on 6 April 2004). 
and effectively took control of the whole process of changes in the electoral system ${ }^{32}$.

The situation seemed calm for almost a decade, but the recent 'Occupy Central standoff', where tens of thousands occupied Central Hong Kong for months, has highlighted that, after two decades of the return of Hong Kong to the PRC, "one country, two systems" is still being finely shaped 'as we go'. On the aftermath of the standoff, the Standing Committee intervened again by issuing another interpretation. In this 2016 interpretation, the provision of the Basic Law at stake related to the taking of oath by public officials. As a result of the interpretation, two directly elected representatives, who flirt with the idea of independence for Hong Kong, were disqualified from their seats in the Legislative Council. While taking the oath of office, the two youngsters pledged allegiance to the "two systems" part of the oath but fudged the part relating to "one country". Also somewhat as a consequence of the standoff, the most recent constitutional move by the Standing Committee consisted of adding the national anthem law to Annex III of the Basic Law. It is not legally clear, as of yet, whether this law creates an obligation for Hong Kong to criminalize acts that correspond to a legitimate exercise of the freedom of expression, at least as this freedom was understood within the previous "way of life" that is to be maintained for 50 years ${ }^{33}$.

All these developments have been shaped by the complex dynamics of the relationship between, on the one hand, the forces for democratization and the courts in Hong Kong, particularly, the HKCFA and, on the other hand, the Central Authorities, a prominent legal and precision guided role being exercised by the Standing Committee and its interpretations ${ }^{34}$. The constitutional picture is that of a bizarre

32 On this interpretation, see DAVIS, Michael, Interpreting Constitutionalism and Democratization in Hong Kong, Interpreting Hong Kong's Basic Law: The Struggle For Coherence, FU, Hualing, HARRIS, Lison and YOUNG, Simon N.M. (eds.), Palgrave, 2007, p. 79-81.

33 The decision to add the National Anthem Law to Annex III was made on 4 November 2017.

34 In fact, although - in relation to issues that the Standing Committee perceives to be "one country" issues - the intervention by the center has been robust, it is remarkable how "very cautiously" the Standing Committee has been exercising its power and it is definitively true that, at least in relation to 
mesh of different interpretative techniques, decision-making habits and 'policy oriented versus rule of law oriented decisions', all of which supposedly producing legal effects within the same jurisdiction. The result is a constitutional system with overlapping layers and operating logics that, possibly, are an inevitable and already ingrained part of "one country, two systems".

In Macau, a smaller, and less unruly, territory, things are less rowdy ${ }^{35}$. In fact, clashes between the institutions of the Macau SAR and the Central Authorities are unheard of. Two major factors explain the Macanese reality. First, unlike in the case of Hong Kong, there are no provisions in the Macau Basic Law mandating a progressive development towards universal suffrage ${ }^{36}$. Second, courts in Macau do not normally assert the same type of constitutional authority as their Hong Kong counterparts $\mathrm{do}^{37}$.

uncontroversial autonomic matters, in which the "larger China" is clearly not an interested party, the Standing Committee and other Central Authorities have let Hong Kong's autonomy work on its own. GITTINGS, Danny, Introduction To The Hong Kong Basic Law, 2nd Edition, Hong Kong University Press, 2016, p. 6 and 310.

35 Of note is that, unlike the case of Hong Kong, Macau passed a Law on National Security smoothly, as mandated by Article 23 of the Basic Laws. Also of note is that a Member recently elected to the Legislative Assembly of Macau was suspended from office by his peers as a result of pending criminal proceedings for (illegally) disobeying police orders during a demonstration. Upon a (relatively reduced) sentence of 120-day fine, amounting to about 5000 US dollars, the young legislator has since retaken his seat in the territory's legislative body.

36 Provisions merely establish the possibility of altering the method of selecting the Chief Executive and the method for forming the Legislative Assembly. See Annex I and II MBL.

37 Compare the following statement of the HKCFA, "[l]ike other constitutions, [the Basic Law] distributes and delimits powers, as well as providing for fundamental rights and freedoms. As with other constitutions, laws which are inconsistent with the Basic Law are of no effect and are invalid. Under it, the courts of the Region have independent judicial power within the high degree of autonomy conferred on the Region" (HKCFA, LING, Ng Ka, par. 64 (emphasis added)) with this one of the Macau CFA: "[a]lthough the Basic Law of Macau shares the characteristics normally associated with the political constitutions of states, formally it is not a constitution because the Macau SAR is not a State". See Tribunal de Última Instância, Case n. 28/2006, 18 July 2007 (emphasis added). Examples of deference of courts in Macau to ordinary legislation 


\title{
2. Judicial cooperation in criminal matters in the Special Administrative Regions
}

As explained in Part I, the proper operation of "one country, two systems" is rather complex. Judicial cooperation in criminal matters is no exception and, arguably, is a textbook illustration of how such complexity translates into a perplexing state of affairs. The Basic Laws enshrine a slightly enigmatic norm on how judicial cooperation tout court might take place between each of the SARs and other parts of the country. According to Articles $95 \mathrm{HKBL}$ and $93 \mathrm{MBL}$

\begin{abstract}
"[t]he Special Administrative Region[s] may, through consultations and in accordance with law, maintain juridical relations with the judicial organs of other parts of the country, and they may render assistance to each other" ${ }^{\prime 3}$.
\end{abstract}

There are no news of these provisions ever being used as grounds for a specific case of judicial cooperation in criminal matters, namely, for the surrender of fugitives ${ }^{39}$. Scholars and others have since long

in detriment of constitutional norms can be found in LEMOS Miguel, "Os 'crimes incaucionáveis' no Código de Processo Penal de Macau”, Estudos em Homenagem ao prof. Doutor Manuel da Costa Andrade, Volume II, Studia Iuridica, Universidade de Coimbra, Maio, 2018; LEMOS, Miguel, Direitos Fundamentais e Processo Penal: o Habeas Corpus, o Direito ao Recurso de Decisão Condenatória e as Funções de Tutela de Direitos Fundamentais do Tribunal de Instrução Criminal, Segundas Jornadas de Direito e Cidadania da Assembleia Legislativa da RAEM, Direitos Fundamentais - Consolidação e Perspectivas de Evolução, Coord. ALVES, Leonel e CARDINAL, Paulo, 2016, p. 257-267. Notwithstanding, as explained in Part III, in some cases, courts in Macau have asserted a robust, but perhaps ineffective, type of constitutional authority.

See Articles 95 HKBL and 93 MBL (emphasis added). On the term "juridical", see BRABYN, Janice M., Extradition and the Hong Kong Special Administrative Region, Case Western Reserve Journal of International Law, 20, 1988, p. 171, 172.

This Article will focus only on this specific aspect of judicial cooperation in criminal matters, which is not only the most symbolic aspect of this type of cooperation but also the one that has raised more controversy in Hong Kong and Macau. Legislation in Hong Kong on judicial cooperation in criminal matters tout court includes the Fugitive Offenders Ordinance (FOO); the Transfer of Sentenced Persons Ordinance and the Mutual Legal Assistance Ordinance (including 'assistance in relation to the taking of evidence and the production of Things', 'assistance in relation to search and seizure', 'assistance in relation 
argued that the legal and political solution for the impasse thus created is in the adoption of agreements between the SARs and the Mainland ${ }^{40}$. Although news of on-going conversations between the SARs and the Central Authorities on these agreements are recurrent, none has seen the light of day yet ${ }^{41}$. As a result, cooperation between the SARs and the Mainland has been left in a legal limbo. As further developed in Part III, this has led to interesting legal questions and peculiar decisions by courts.

to production etc. of material', 'transfer of persons to give assistance in relation to criminal matters', 'assistance in relation to confiscation, etc. of proceeds of crime' and 'service/certification of documents'); the Drug Trafficking (Recovery of Proceeds) Ordinance 1986; and Hong Kong Evidence Ordinance. BRABYN, Janice, Inter-jurisdictional Co-operation in Criminal Matters: Extradition, Mutual Legal Assistance, Prisoner Transfer to and From the HKSAR, in WACKS, R. (ed), The New Legal Order in Hong Kong, Hong Kong: Hong Kong University Press, 1999, p. 149-156 (on cooperation with the Mainland, see ibidem, p. 157-159). In Macau, the applicable main piece of legislation is Law 6/2006, on judicial cooperation in criminal matters. According to Law $6 / 2006$, judicial cooperation in criminal matters encompasses the surrender of fugitives, transfer of proceedings, execution of criminal penalties, transfer of sentenced persons, surveillance of sentenced persons or persons on parole and other forms of judicial cooperation in criminal matters.

40 The use of the expression "the Special Administrative Region[s] may", which logically also implies "may not", surely reinforces the argument that the adoption of some sort of negotiated agreements between the Mainland and the SARs to regulate judicial cooperation in criminal matters is not excluded from the scope of the provision. On this see BINGZHI, Zhao, Estudo dobre a questão da cooperação judiciária em matéria penal entre o interior da China e as Regiões Administrativas Especiais de Hong Kong e de Macau, Revista Jurídica de Macau, número especial, 2004, p. 74-80, particularly, p. 79-80; As of today, it seems settled that the most appropriate method to deal with the issue is through negotiated agreements or arrangements between the Central Authorities and the SARs. Of note is that several arrangements were already made and are in force between the two SARs. On criminal matters, see Arrangement between the Government of the Hong Kong Special Administrative Region and the Government of the Macau Special Administrative Region on the Transfer of Sentenced Persons, signed in Hong Kong on 20.5.2005 and Cooperative Arrangement between Correctional Services Department of the Hong Kong Special Administrative Region and Macao Prison of the Macao Special Administrative Region, signed in Macao on 29.3.2006. On these agreements and transfer of sentenced persons within the PRC in general, see WAN, Choy Dick, Prisoner Transfer between Hong Kong and Mainland China: A Preliminary Assessment, Brooklyn Journal of International Law, 2008, p. 500-501.

On why the conclusion of these agreements has proved so difficult, see Part. III. 
In contrast, judicial cooperation in criminal matters between the SARs and foreign countries runs quite smoothly ${ }^{42}$ under the normal principles applicable to judicial cooperation in criminal matters. In general, under a broad authorization of the Central People's Government for the SARs "to conduct relevant external affairs on [their] own in accordance with [the Basic Laws]" ${ }^{43}$, this cooperation is conducted by the SARs' Governments pursuant to their powers "to maintain and develop relations and conclude and implement agreements with foreign states" ${ }^{44}$. In particular, such cooperation is conducted, "with the assistance or authorization of the Central People's Government", in order to "make appropriate arrangements with foreign states for reciprocal juridical assistance” ${ }^{45}$.

Several such arrangements have been concluded and "have taken the form of either bilateral agreements ${ }^{46}$ or multilateral conventions ${ }^{47}$ that are applied [in the SARs]"48.

42 This conclusion is subject to a more careful assessment, which cannot be carried out in this Article, of the Snowden case. On this case, see KIELSGARD, Mark D. and IP, Ken Gee-Kin, Hong Kong's Failure To Extradite Edward Snowden: More Than Just A Technical Defect, 13 Rich. J. Global L. \& Bus 49, Spring, 2014, arguing that extradition from Hong Kong to the United States would probably not have been granted by Hong Kong courts if Snowden had remained in Hong Kong.

HKBL 13, MBL, 13.

HKBL 151, MBL 136 (emphasis added).

HKBL 96, MBL 94.

46 The Government of the HKSAR has so far signed agreements with twenty jurisdictions on the surrender of fugitive offenders. For a list of List of Surrender of Fugitive Offenders Agreements in Hong Kong see https://www. doj.gov.hk/eng/laws/table4ti.html. It has also signed agreements on mutual legal assistance in criminal matters with thirty-two foreign jurisdictions. https://www.info.gov.hk/gia/general/201806/20/P2018062000419.htm. For the less extensive list of agreements on judicial cooperation in criminal matters in force in Macau, see https://www.io.gov.mo/pt/legis/int/list/ bilat/juridical.

47 In Hong Kong, several multilateral treaties containing obligations regarding surrender of fugitives and "requiring enabling legislation especially given their extraterritorial application” apply. LIM, C.L. \& MUSHKAT, R., External Affairs, in CHAN, J.M.M. Chan \& LIM, C.L. (eds), Law of the Hong Kong Constitution, 2nd ed (Hong Kong: Sweet \& Maxwell, 2015),p., p. 112, marg. 3087, n. 120. For Macau, see https://www.io.gov.mo/pt/legis/int/list/multi/crime. 
The constitutional, international and legal framework applicable to the surrender of fugitives between the SARs and foreign states is vast and mostly raises the same legal questions as in other places in the world. It suffices to provide an overview of the main principles applicable in each of the SARs, which can be found in the two main pieces of legislation relevant to the matter: in Hong Kong, the above-mentioned Fugitive Offenders Ordinance (Cap. 503) and, in Macau, the above-mentioned Law 6/2006. The process of the surrender of fugitives is executed in both SARs by means of decisions of the Chief Executives ${ }^{49}$ and courts ${ }^{50}$. Notification of the process to the Central People's Government is required ${ }^{51}$.

According to prevailing opinion such arrangements, laws and decisions "have largely followed [...] international practice, in terms of both the conditions set out for the surrender of fugitive offenders and the required safeguards" ${ }^{2}$.

49 Section III of the FOO, in Hong Kong, and Article 22 Law 6/2006, in Macau. See also Articles 48 (9) HKBL and 50 (13) MBL ("the Chief Executive[s] of the [...] Special Administrative Region[s] shall [...] conduct, on behalf of the Government[s] of the Special Administrative Region[s], external affairs and other affairs as authorized by the Central Authorities") and Articles 62 (3) HKBL and 64 (3) MBL ("[t]he Government[s] of the [...] Special Administrative Region[s] shall [...] conduct external affairs as authorized by the Central People's Government under this Law")

50 On the procedure, in Hong Kong, see FOO, Sections 6-16. For a summary in the Macau case, see FERREIRA, Ilda Cristina, The Surrender of Fugitives offenders in Macao SAR, 2016, p. 307, 308.

51 See, in Hong Kong, Section 24 of the FOO and, in Macau, Law 3/2002. The Central People's Government may issue instructions to the Chief Executive of the SARs "to take, or not to take, an action". See particularly Section 24 (3) FOO and Article 4 Law 3/2002. See also Articles 48 (8) HKBL and 50 (12) MBL ("the Chief Executive[s] of the [...] Special Administrative Region[s] shall [...] implement the directives issued by the Central People's Government in respect of the relevant matters provided for in this Law"). Such is a consequence of the circumstance that the Central People's Government is the responsible body for all matters affecting foreign affairs and defense. See KIELSGARD, Mark D. and IP, Ken Gee-Kin, Hong Kong's Failure To Extradite Edward Snowden, cit., p. 52, informing that "Hong Kong has traditionally exercised its authority without interference from the Central Government [and that] there is no credible evidence suggesting that the [Central government] has ever directly overridden the Hong Kong Courts on extradition issues in the past".

52 LIM, C.L. \& MUSHKAT, R., External Affairs cit., p. 112, marg. 3087 (speaking of the Hong Kong case). See also FERREIRA, Ilda Cristina, The Surrender of 
As to the substantive conditions required for cooperation to proceed, one can find some normal rules on the matter that are common to both SARs, including 'double criminality'53, 'speciality' and 'no resurrender to a third jurisdiction' 54 , 'non bis in idem'55, 'no political offences ${ }^{56}$, 'no discrimination' ${ }^{57}$, and 'no surrender if death penalty'. ${ }^{58}$

Some differences do exist. Below are just some examples.

Under the influence of Portuguese law, the same legal framework that applies in both jurisdictions to 'no surrender if death penalty'59 applies in Macau (but not in Hong Kong) to life imprisonment and to penalties of indefinite duration ${ }^{60}$.

Under the influence of British law, there is in Hong Kong the requirement that a 'prima facie case [be made] on the face of available evidence' ${ }^{61}$. Although such a safeguard does not exist under Law 6/2006 in Macau, which actually prohibits such an undertaking ${ }^{62}$, there is room for the Chief Executive of Macau to refuse cooperation when the manifest insufficiency of evidence would make cooperation contravene the international public order of the PRC and/or of the Macau SAR ${ }^{63}$.

Fugitives offenders in Macao SAR cit., p. 303 (speaking of the Macau case).

53 Minimum requirement of: more than 12 months (Hong Kong); not below one year (Macau). See Foo, Section 2 (2) and Law 6/2006, Article 32 (2).

54 See, for Hong Kong, Section 5 (2) to (7) FOOO. For Macau, see 46 (3) Law $6 / 2006$.

55 Section 5 (1) e FOO; 9 and 20 Law 6/2006.

56 5(1) a FOO; Article 8 Law 6/2006.

57 Section 5 (1) c, d FOO; Article 7 (1) 2 Law 6/2006.

58 No extradition if death penalty or if no assurances it will not be imposed or executed. Section 13 (5) FOO; Article 7 (1) 7 and 7 (2) 1 and 2 of Law 6/2006. See footnote 56.

60 Article 7 (1) 6 and 7 (2) 1 and 2 of Law 6/2006.

61 Section 10 (6) b iii of the FOO. ("the evidence in relation to the offence would be sufficient to warrant the person's committal for trial according to the law of Hong Kong if the offence had been committed within the jurisdiction of that court or any other court").

62 Article 48 (3) Law 6/2006 ("no evidence whatsoever is admitted on the facts alleged against the person").

${ }^{63}$ Article 48 (2) Law 6/2006 ("[t]he administrative phase is of the responsibility of the Chief Executive and is intended to assess whether the request for 
Similarly, "in line with the practice in common law jurisdictions not to refuse surrender of own nationals, the Government [of Hong Kong does] not refuse to surrender nationals of China or Hong Kong Permanent Residents" ${ }^{64}$, albeit Section 13 (4) of the FOO provides for the "right to refuse the surrender of Chinese nationals". Apparently, this provision has

"so far not been invoked and was intended to be used very rarely. The main reason for such a provision in surrender of agreements for the surrender of fugitive offenders was to cover a situation in future where arrangements existed to permit the rendition of persons from HKSAR to the Mainland, and both PRC and the requesting foreign jurisdiction had jurisdiction concurrently over the same offence. Such a provision would enable priority to be given to a Mainland request for the rendition of a Mainland Chinese national over a foreign request for the extradition of the same person for the same offence" ${ }^{55}$.

In Macau, in line with Portuguese and continental law practice, surrender is refused if the person is (1) a Chinese national non-resident of Macau or (2) a resident of $\mathrm{Macau}^{66}$. Interestingly, the principle aut dedere aut judicare only seems to apply to the latter case; not to the former. It seems that the rationale of the norm consists of the following: while the resident of Macau must be prosecuted in Macau, the Chinese

surrender of a fugitive [...] should be declared inadmissible for reasons of political order or opportunity or convenience"). On this see COSTA, Miguel João, Dedere aut judicare? A decisão de extraditar ou julgar à luz do direito português, europeu e internacional, Instituto Jurídico da Faculdade de Direito da Universidade de Coimbra, Junho 2014, p. 27, 28, reasoning on the Portuguese law on cooperation and arguing that in such cases there is a duty for the Government, and even for the judiciary, to refuse cooperation. See also DIAS, Jorge de Figueiredo, Algumas questões em tema de extradição e de sede do crime [anotação], Revista de Legislação e Jurisprudência,118 (1985), p. 15 and ff. LIM, C.L. \& MUSHKAT, R., External Affairs cit., p. marg. 3087, n. 123.

Subcommittee on Fugitive Offenders (Finland) Order Background brief prepared by the Legislative Council Secretariat. https://www.legco.gov.hk/ yr05-06/english/hc/sub_leg/sc53/papers/sc530306cb2-1290-2e.pdf.

66 Article 33 (1) 2 and 3 Law 6/2006. In the case of a resident of the Macao SAR an exception exists if the request is made by the state of the persons' nationality or when the obligation to surrender flows from a self-executing norm in a treaty applicable to Macau. 
national non-resident of Macau must be surrendered for prosecution to the authorities of the Mainland, which would then be under the obligation to prosecute the person. Arguably - taking into account that there is a legal vacuum on the question of surrender of fugitives to the Mainland and, hence, such surrender is illegal ${ }^{67}$ - there is a loophole in Law 6/2006, as the person turns out to be subject neither to surrender to the Mainland nor to prosecution in Macau ${ }^{68}$.

In relation to 'convictions in absentia', surrender is automatically denied by the Hong Kong authorities if "the person (A) has not had an opportunity of being tried in his presence for that offence; and (B) if surrendered, would not have an opportunity of being re-tried in his presence for that offence" ${ }^{69}$. In Macau, apparently, such denial is not automatic, albeit there is the possibility for cooperation not to proceed if "[c] opy of the legal texts relating to the possibility of appealing the decision or retrial, [if conviction in absentia]" is not provided ${ }^{70}$.

Although there are some important differences, the overall resemblance between the constitutional, international and legal frameworks of the two SARs on this issue is relatively high. Therefore, it is not hard to predict that, if they ever see the light of day, the cooperation agreements to be established between each of them and the Mainland will be similar ${ }^{71}$, irrespective of whether or not many, or some, of these rules are suitable to, or will actually apply to, the future "one country, two systems" surrender of fugitives cooperation ${ }^{72}$.

67 See decisions of the Court of Final appeal of Macau below Part III.

68 On this, see LEMOS, Miguel, "Direitos Fundamentais e Processo Penal: o Habeas Corpus”, cit., p. 265. See also Part III.

695 (1) b ii of the FOO.

70 See Articles 46 (2) 6, 47 and 48 of Law 6/2006.

71 See also BINGZHI, Zhao, "Estudo dobre a questão da cooperação judiciária em matéria penal”, cit., p. 46-47.

72 Note, however, that this does not mean that the rules to be included in such agreements have to follow closely the substantive or procedural rules of international cooperation on judicial matters currently in force in the SARs. Possibly having this in mind, the HKSAR Security Bureau has already suggested that the "usual safeguards" included in the legislation of Hong Kong would be merely "of useful reference", thereby hinting that there is no "legal obligation to include these safeguards" in future agreements. See YEE, Marsha 


\section{The surrender of fugitives to Mainland China}

By definition, surrender of fugitives within the PRC is not a question of international judicial cooperation in criminal matters but of internal judicial cooperation. The legally complex problem lies in that very unalike constitutional documents and laws govern the Mainland and SARs. Thus, under the uniqueness of "one country, two systems" described in Part I, the framework for cooperation on surrender of fugitives that one day might take shape between the Mainland and the SARs will certainly be rather sui generis ${ }^{73}$.

Indeed, the main difficulty on the conclusion of a general agreement on judicial cooperation on criminal matters lies, more than anything else, in the issue of surrender of fugitives. The nature of the difficulty was well depicted by Margaret Ng. While the government of

Wellknown, Hong Kong's legal obligation to require fair trial for rendition, 102 Colum. L. Rev. 1373, June, 2002, p. 1383. That is certainly true, as long as the rules of Basic Laws of the SARs are respected. The fact that Articles 95 HKBL and 93 MBL are also constitutional rules does not mean that unlimited leeway for any type of cooperation whatsoever is to be deemed in accordance with the Basic Laws. See also GUOQIANG, Zhao, Auxílio judiciário mútuo inter-regional na China sob as condições de 'um país, dois sistemas', Revista Jurídica de Macau, No Especial, 2004, p. 105-109. In other words, Articles 95 HKBL and 93 MBL have to be interpreted in harmony with the other rules of the Basic Laws, including the constitutional rules of international origin that have constitutional force in the SARs, most prominently the rules of the ICCPR, whose constitutional rank in the SARs derives from Article 39 HKBL and 40 MBL. Similarly, special attention must be paid to the fundamental aspects of the law previously in force in Hong Kong and Macau. See Joint Declaration on the question of Hong Kong, par. 3 (3), and Joint Declaration on the question of Macau, par. 2 (4): "the fundamentals of the law currently in force in Hong Kong [and Macau] will remain basically unchanged". This wording flows from the Chinese version of the Joint Declarations (“现行的法律基本不变”). Less accurately, the English and Portuguese versions state that [t]he laws currently in force in Hong Kong [and Macau] will remain basically unchanged". Of course, not all the laws will remain basically unchanged; laws can be even revoked. What should remain basically unchanged are the fundamentals aspects of the legal system previously in force. On two grounds for refusal that might prove controversial in the Mainland-SARs context, namely the "death penalty" and "political offence" exceptions, see BRABYN, Janice, Inter-jurisdictional Co-operation in Criminal Matters cit. p. 160. 
Hong Kong affirmed that dual criminality would be a requirement to be included in any such agreement, Ng put forward that:

"this sort of safeguard will not be good enough for the realities of a Mainland-HKSAR agreement, because the problem here lies in the two extremely different legal and judicial systems, particularly relating to the recognition of fundamental rights, including the right to an open and fair trial. Hence the bottom line for the negotiation for a rendition agreement must be no rendition of any person from Hong Kong without guarantee for his rights, including the right of an open and fair trial by international human rights standards. One can see the difficulty of the HKSAR government officials in putting forward a position which acknowledges a deep mistrust in the mainland system. It is probably far too impolite to speak the truth. However, until and unless this problem is overcome, Hong Kong will not be better off with a rendition agreement"74.

And thus, as agreements and/or laws setting up the general legal framework governing these cases have yet to be concluded or enacted, one could be led to think that internal cooperation for the arrest and surrender of fugitives between the SARs and the Mainland is stalled. In other words, the absence of specific norms on how to restrict the constitutional "inviolable freedom" of persons ${ }^{75}$ for the purpose of arrest and

74 LO, Shiu Hing, The Politics of Cross-Border Crime in Greater China: Case Studies of Mainland China, Hong Kong, and Macao (Hong Kong Becoming China), (East Gate, 2009), p. 182 (emphasis added). On requiring fair trial for rendition, see YEE, Marsha Wellknown, Hong Kong's legal obligation to require fair trial for rendition cit.

75 In the SARs, relevant constitutional norms include Article $28 \mathrm{HKBL}$ and MBL ("[t]he freedom of the person of [...] residents shall be inviolable. No [...] resident shall be subjected to arbitrary or unlawful arrest, detention or imprisonment. Arbitrary or unlawful [...] deprivation or restriction of the freedom of the person shall be prohibited"); Article $31 \mathrm{HKBL}$ and Article 33 MBL (" $[\mathrm{u}]$ nless restrained by law, holders of valid travel documents shall be free to leave the Region without special authorization"); Article 39 HKBL and Article $40 \mathrm{MBL}$ ("[t]he rights and freedoms enjoyed by [...] residents shall not be restricted unless as prescribed by law") (emphasis added); Article $41 \mathrm{HKBL}$ and Article $43 \mathrm{MBL}$ ("[p]ersons in the [...] Special Administrative Region[s] other than $[. .$.$] residents shall, in accordance with law, enjoy the rights and$ freedoms of [...] residents"). See also Articles 9, 12 and 13 of the ICCPR. 
surrender of fugitives within different jurisdictions of the PRC would constitute an unsurmountable obstacle to cooperation on this matter ${ }^{76}$.

Reality is a bit more complex. On the one hand, the alleged mistrust has long only worked one-way. From the Mainland side of the border, authorities have frequently surrendered back to Hong Kong and Macau fugitives suspect to having committed crimes in Hong Kong and $\mathrm{Macau}^{77}$. On the other hand, from the SARs side of the border, cooperation has also for long been 'kind of' alive.

76 In relation to Hong Kong, as part of the British Empire, the absence of a prerogative power to extradite can be traced back to 1815. BRABYN, Janice, Inter-jurisdictional Co-operation in Criminal Matters cit. p. 135, n. 9. See also, on the Macau case, OLIVEIRA, Jorge Costa, Macau SAR Inter-Regional Mutual Legal Assistance in Criminal Matters, One Country, Two Systems, Three Legal Orders - Perspectives of Evolution. Essays on Macau's Autonomy after the Resumption of Sovereignty by China, Springer- Verlag Berlin Heidelberg, 2009, p. 568 ("assistance that is not covered or foreseen by law is unlawful and therefore cannot be rendered").

77 This apparent existence of a non-reciprocal relationship is officially alleged. The former Secretary for Justice in Hong Kong, Elsie Leung, reportedly affirmed that "[n]ormally, fugitive offenders will be sent back to Hong Kong but the practice is not reciprocated for mainland criminals”. LIM, C.L. \& MUSHKAT, R., External Affairs cit., p. 115, n. 136. According to CHEUNG, Elsie, between 1990 and 1998, 128 fugitives were returned from the Mainland. LO, Shiu Hing, The Politics of Cross-Border Crime in Greater China, p. 180. See also BRABYN, Janice M., Extradition and the Hong Kong Special Administrative Region cit., p. 183-185, alluding to a case where the Mainland returned a fugitive to Macau. This informal co-operation based upon 'tacit understandings' was described in 1994 by Regina Yip, then Assistant Secretary in Hong Kong, as follows: "[i]f we suppose there are [Hong Kong] criminals in China, we send [the authorities] intelligence and information about them. We don't ask for them back, though, because that would be extradition and Hong Kong would need a legal basis for it. [If the Chinese authorities found the Hong Kong criminals] they expelled them as 'unwelcome persons', which was not extradition”. BRABYN, Janice, Inter-jurisdictional Co-operation in Criminal Matters, cit. p. 157, 158. See also YEE, Marsha Wellknown, Hong Kong's legal obligation to require fair trial for rendition cit., p. 1375, 1376, informing that " $[\mathrm{t}]$ he polities currently have a one-way administrative arrangement through which the Mainland returns HKSAR residents to the HKSAR for investigation or trial if they are suspected of having committed offences solely in the HKSAR; the Mainland has not surrendered its own residents to the HKSAR; [t]he HKSAR, in contrast, has not returned anyone to the Mainland because such an action "cannot be done in the absence of a formal arrangement which is supported by legislation' ". 
Actually, provisions directly on point have existed in the past and they suggest a not very demanding kind of cooperation. In Hong Kong, some ordinances were enacted to give effect to Article IX of the 1843 Supplementary Treaty of Bogue ${ }^{78}$, which provided that,

"[i]f lawless Natives of China, having committed crimes, or Offences, against their own Government, shall flee to Hongkong or to the English Ships of War or English Merchant Ships for refuge; they shall, if discovered by the English Officers, be handed over once to the Chinese Officers for trial and punishment; or if, before such discovery be made by the English Officers, it should be ascertained, or suspected, by the Officers of the Government of China whither such criminals and Offenders have fled, communication shall be made to the proper English Officer, in order that the said criminals and Offenders may be rigidly searched for, seized, and, on proof or admission, of their guilt, delivered up" ${ }^{\text {"79 }}$.

In Macau, centuries old seemingly unconditional and expedite practice received official stamp with the Treaty of Peking of $1887^{80}$, which Article XLV provided in no uncertain terms that

"as to the surrender of Portuguese and Chinese criminals, with the exception of the Chinese criminals who take refuge in Macau

78 On these ordinances, see BRABYN, Janice M., "Extradition and the Hong Kong Special Administrative Region", cit., p. 183-85.

79 Treaty of the Bogue. Supplementary Treaty Signed By Their Excellencies Sir Henry Pottinger and Ki Ying Respectively, On The Part Of the Sovereigns of Great Britain and China, At the Bogue, 8th October 1843. As to British fugitives, the treaty provided that "[i]n like manner, if any Soldier or Sailor or other person, - whatever his Caste or Country, - who is a Subject of the Crown of England, shall from any cause, or on any pretence, desert, fly, or escape into the Chinese Territory, such Soldier, or Sailor, or other person, shall be apprehended and confined by the Chinese Authorities, and sent to the nearest British Consular; or other Government Officer. In neither else shall concealment or refuge be afforded".

80 The treaty was signed in 1 December 1887 and ratified in 28 April 1888. Treaty of Beijing, China-Port., Dec. 1, 1887, reprinted in Godfrey E.P. Hertslet, Treaties, Etc., between Great Britain and China and between China and Foreign Powers; and Orders in Council, Rules, Regulations, Acts of Parliament, Decrees, Etc., affecting British interests in China 422 (3d Ed. 1908). 
and for whose extradition the governor of Macau will continue to follow the practice thus far followed upon receiving a request of the Vice-King of the two Quangs, it is agreed that, in the Chinese ports that are open to foreign commerce, the Chinese criminals that take refuge in the dwellings or on board of ships of Portuguese subjects, will be arrested and surrendered to the Chinese authorities as soon as they so request to the Portuguese consul" ${ }^{\prime 1}$.

Irrespective of whether or not these provisions were commonly used and whether or not cooperation mostly escaped official channels, they lost their usefulness around seven decades ago due to the refusal by the PRC to take advantage of the "unequal treaties" or any related legislation $^{82}$.

In fact, official relations between Hong Kong (Great Britain) and Macau (Portugal), on the one side, and the Mainland (China), on the other side, never proceeded without difficulty ${ }^{83}$. Thus, it is not a wild guess that for centuries cooperation on this matter has mainly consisted of in casu practical - non-official or quasi-official - responses that follow ad-hoc informal procedures and are conducted by the police and/or the prosecutorial authorities of the old, and now of the new, Hong Kong and $\mathrm{Macau}^{84}$. Although the available data on this issue is minimal, some

81 As to Portuguese fugitives, the treaty provides that "and, hence, also the Portuguese criminals that take refuge in China will be arrested and surrendered to the Portuguese authorities as soon as they so request to the Chinese authorities, and no criminals shall be harbored by any of the parties and there will be no delay in their surrender" (emphasis added).

82 On the Chinese authorities' reliance, prior to 1939, upon Hong Kong ordinances on the surrender of Chinese citizens to the Mainland, see BRABYN, Janice M., Extradition and the Hong Kong Special Administrative Region cit., p. 185, n. 92. On the "unequal treaties", see WANG, Dong, China's Unequal Treaties: Narrating National History, Lexington Books, 2005.

${ }^{83}$ On this, for Hong Kong, see WANG, Dong Wang, China's Unequal Treaties: Narrating National History cit., and, for Macau, PEREIRA, Francisco, Portugal, China e a "Questão De Macau" cit.

84 Writing in 1988 Janice Brabyn considered that "it is possible that informal cooperation in the nature of disguised extradition on the part of Hong Kong may occur but the author has been unable to document this". BRABYN, Janice M., Extradition and the Hong Kong Special Administrative Region cit., p. 183-85. Later on, the same author reported, in relation to Hong Kong, on: (1) "informal extradition of illegal immigrants, known or unknown fugitives 
cases do come to public attention from time to time and enable us to have a glimpse on the nature of such long-standing de facto cooperation. This type of cooperation was always the natural consequence of the circumstance that, despite the fact that official ties with the Mainland have for centuries been under strain, Hong Kong and Macau were never truly separated from it, be it in a physical, economic, cultural, etc. sense $\mathrm{e}^{85}$. This status quo has not impressively changed with the return of Hong Kong and Macau to the "embrace of the Mainland".

Overall, on a pragmatic note, it is important to keep in mind that the peculiar kind of in casu practical responses and ad-hoc informal procedures that have long been used to handle the "surrender of fugitives to Mainland China issue" are nothing more than controversial devices deployed to overcome the absence of a general framework that is long due ${ }^{86}$.

amongst them"; (2) "escort of fugitives back to the mainland by PRC public security bureau personnel"; and (3) the possibility of "arrest and return to the PRC”. BRABYN, Janice, Extradition and the SARs After Reunification, Macau Law Journal, 2002, p. 82-86, also informing, in relation to Macau, on: (1) an "informal agreement as to extra-judicial surrender" between in the PRC and Macau; (2) a case where a foreigner was surrendered by the Macau police to the PRC authorities; (3) the circumstance that, since 1993, the PRC made five requests for surrender from Macau pursuant to the Portuguese Extradition Law of 1975. On formal surrender of fugitives from Hong Kong to Macau and "less formal co-operation between the authorities of the two jurisdictions [as] inevitable", see Janice Brabyn, "Extradition and the SARs After Reunification", p. 86. On "disguised extradition" which, at present, is possibly the most commonly used informal procedure ensuring that fugitives are surrendered to the Mainland, see below.

As Professor Zhao metaphorically explains, "the relationship between Hong Kong, Macau and the Mainland is as close as that of between the lip and the teeth and as interdependent as that of as between the flesh and the blood". GUOQIANG, Zhao, "Auxílio judiciário mútuo inter-regional na China sob as condições de "um país, dois sistemas", cit. p. 101.

86 This is one of those areas of law where the "normative force of constitutions" has to be confronted with the "normative force of facts" and, possibly, law is here "gravitating around itself". CANOTILHO, Gomes, As Palavras e os Homens, reflexões sobre a Declaração Conjunta Luso-Chinesa e a institucionalização do recurso de amparo de direitos e liberdades na ordem jurídica de Macau, Revista Jurídica de Macau, número especial sobre O Direito de Amparo em Macau e no Direito Comparado, 1999, p. 116. From both a political and constitutional/legal perspective, the status quo might be cause for concern but this is not the place carry an analysis from any of these perspectives. 
In the new Hong Kong SAR, the "issue became a matter of controversy" soon after the handover, in 1998, when a Hong Kong resident was sentenced to death by a court in Guangzhou ${ }^{87}$ and executed by shooting on 5 December 1998 for crimes allegedly also committed in Hong Kong88. However, although controversy related to the possibility that crimes committed in Hong Kong could be punished in Mainland China, it was a clear case of concurrent jurisdiction and no surrender of fugitives issue was at stake ${ }^{89}$. Other cases that came to public attention, where crimes apparently perpetrated only in Hong Kong were prosecuted in Mainland China, occurred in $1999^{90}$ and $2003^{91}$. But again, no surrender of fugitives occurred in these cases. The controversial - but, in the opinion of the authors of this Article, rather unproblematic - legal issue in these cases only concerned the extra-territorial jurisdictional broad scope of the PRC's Criminal Law, which purports itself to apply to Chinese citizens who commit crimes "outside the domain of the PRC"92. Although Hong Kong is

Concerning the former for obvious reasons. The analysis of the latter requires a longer engagement with the constitutional/legal norms applicable in each one of the SARs. It is not possible to undertake here such analysis, which can be found elsewhere. LEMOS, Miguel, Direitos Fundamentais e Processo Penal: o Habeas Corpus cit., p. 257-267. For the purposes of this Article, it is more adequate to provide the readers with an overview of the cases that came to public attention, the reaction of courts and academics and the radically opposing views on how the problem should be handled. This is done immediately below in the main text.

Capital of Guangdong, the PRC's province bordering the SARs.

LIM, C.L. \& MUSHKAT, R., External Affairs cit., p. 113, marg. 3088. See also CULLEN, Richard and FU, H.L., "Some Basic Limitations in the Basic Law Exposed", China Perspectives, No 22 March-April 1999, p. 57, arguing that, in this case, there were "clear reasons" why the Hong Kong Government should have made a request for surrender of the fugitive through the informal "administrative arrangements" that exist to move suspects across the border.

On this case, see LO, Shiu Hing, The Politics of Cross-Border Crime in Greater China, p. 180-183. LO, Shiu Hing, The Politics of Cross-Border Crime in Greater China, p. 180-183.

Mainland, HK plan talks on extradition, China daily, 5 December 2003, http://www.chinadaily.com.cn/en/doc/2003-12/05/content_287718.htm.

See Article 7 PRC's Criminal Law. On the controversial nature over the meaning of the word "domain" used in Article 7 and the "proper demarcation of the scope of criminal jurisdiction of Hong Kong and China”, see LIM, C.L. \& MUSHKAT, R., External Affairs cit., p. 113, 114, marg. 3093. 
manifestly not outside the domain of the $\mathrm{PRC}^{93}$, there is no interpretation rule impeding Mainland courts to consider that the proper construction of such provision encompasses all places outside the territorial scope of the PRC criminal law, including Hong Kong and Macau ${ }^{94}$.

The only case in the new Hong Kong SAR that came to public attention, and where such informal and ad-hoc procedures were used, is the case of Zhou Yongjun, one of the students leaders of the 1989 movement for democracy ${ }^{95}$. Apparently, he was surrendered by Hong Kong authorities to the Mainland authorities ${ }^{96}$ under what can be called a "disguised surrender" ${ }^{97}$. Subsequently, he was prosecuted

93 Article 1 of the Basic Laws state that "The [...] Special Administrative Region[s] [are] an inalienable part of the People's Republic of China".

94 In general, see also CULLEN, Richard and FU, H.L., "Some Basic Limitations in the Basic Law Exposed", p. 54-56. Some national laws relating to "one country" issues are listed in Annex III of the Basic Law and are applied in the SARs by way of promulgation or legislation by the SARs themselves. The PRC Criminal Law is not one of such laws. The Nationality Law is.

95 LIM, C.L. \& MUSHKAT, R., External Affairs cit., p. 113, marg. 3091.

96 The press realease of the Hong Kong Government on Zhou Yongjun's case stated that " $[\mathrm{w}] \mathrm{e}$ do not comment on individual cases. The Immigration Department has the responsibility to uphold effective immigration control. The department handles all entry applications in accordance with the law and immigration policy, having due regard to individual circumstances. In general, a passenger whose travel document does not meet the entry requirements will be repatriated to his or her place of embarkation or origin". http://www. info.gov.hk/gia/general/200910/12/P200910120217.htm (emphasis added). Subsequently, the Government denied knowingly handed over the dissident. https://www.scmp.com/article/705378/minister-denies-hk-knowingly-handed-over-dissident. Under its immigration laws, the HKSAR may send back a Mainland resident who entered illegally or who entered legally but overstayed. Yee, Marsha Wellknown, Hong Kong's legal obligation to require fair trial for rendition cit., n. 15.

97 On this, see BRABYN, Janice M., Extradition and the Hong Kong Special Administrative Region cit., p. 183-185, considering that "[n]ormally, deportation or expulsion is intended simply to remove a person from the territory of a particular state. Then a deporting state has little interest in the destination of the deportee, except to ensure that it is one by which the deportee will be accepted. Sometimes the prime concern is to return a person to a particular state for criminal prosecution and punishment with deportation merely being the method selected to achieve this end. This is really extradition in disguise, hence the common term 'disguised extradition'”. BRABYN notes that "deportation does not become a disguised extradition simply because 
in the Mainland ${ }^{98}$. But the most interesting event concerning this issue, and where an 'unconditional and expedite' kind of "disguised surrender" most probably occurred, relates with two 2007 and 2008 interesting decisions of the Court of Final Appeal in Macau ${ }^{99}$. The issues in both decisions arise from two very similar situations. In both cases, Chinese citizens, permanent residents of the Hong Kong SAR, were arrested on arrival by ferry to the Hong Kong Maritime Ferry Terminal in Macau. Following the arrest, two habeas corpus requests were filed, in one case by the brother, in the other case by the sister, of the person under arrest. Moreover, in both cases the arrest related to crimes committed in the Mainland and an Interpol Red Notice ${ }^{100}$ had been issued at the request of the Mainland authorities. Common to both cases is the existence of orders from an Adjunct Prosecutor "determining", or "agreeing with", the surrender of the person under arrest to the authorities of the Mainland. How the Macau CFA decided to tackle both cases was also similar. It relied on a provision of the Code of Criminal Procedure that, under the heading "surrender of

the authorities of the state to which a deportee is sent are coincidentally anxious to prosecute or punish the deportee for a criminal offense. The term 'disguised extradition' is only appropriate where achieving the function of extradition is one of the principal motivations for the deportation”. In effect, of relevance to this Article is only a forced deportation of a person through the border with the Mainland with the purpose of subjecting the person to criminal proceedings in the Mainland. It is not clear whether normally such 'disguised extradition' occurs by means of direct surrender of the person by the Hong Kong or Macau polices to the Guangdong police or through an expulsion through the border while the Mainland authorities await on the other side for the person to enter Mainland jurisdiction. In Macau, direct surrender might be the most common situation. See GUOQIANG, Zhao, Auxílio judiciário mútuo inter-regional na China sob as condições de "um país, dois sistemas" cit, p. 95, 101, describing a tacit agreement between the authorities of Macau and Guangdong on the surrender of fugitives from Macau back to the Mainland.

98 MACARTNEY, Jane (21 January 2010), Chinese democracy leader Zhou Yongjun jailed for fraud, The Times.

99 Decisão Tribunal de Última Instância 12/2007, 20 Março; Decisão Tribunal de Última Instância 3/2008, 12 Fevereiro.

${ }^{100}$ A Red Notice is a request to law enforcement worldwide to locate and provisionally arrest a person pending extradition, surrender, or similar legal action. https://www.interpol.int/How-we-work/Notices/Red-Notices. 
delinquents", reads: "surrender of delinquents to another Territory or State is regulated by special law" ${ }^{101}$.

As the only special law existing on this matter is the abovementioned Law 6/2006, which only applies to states or territories outside the PRC, the court determined that, under the law, an arrest and surrender cannot occur. However, the facts on the ground got ahead of the Macau CFA. In the first case, the court ordered the release of the person under arrest. That is not what the court should have done. The court should have "ordered, by phone if necessary, the immediate presentation of the detainee" ${ }^{102}$. Arguably, if the Macau CFA had proceeded as the law mandates, it would have been able to prevent the de facto surrender of the person to the authorities of the Mainland, which was possibly taking place at the same time the court was delivering its decision. In the second case, a year later, by the time the Macau CFA was going to deliver its decision on the habeas corpus request, it had already been informed that the person under arrest had been surrendered to the Mainland under the order of an Adjunct Prosecutor, a high-rank prosecutorial authority, second only to the Prosecutor of the Macau SAR. Faced with a blatant non-compliance with its previous decision, the CFA uttered the following surprising words:

"that is, considering that this court had already ruled, by Judgment of 20 March 2007, that it was unlawful to surrender the fugitive to the authorities of Mainland of China, [the Macau prosecutorial authorities] still persist in carrying out such surrender, with no law or agreement which provides for it, without allowing the person under arrest to defend him/herself and without an order from a judge. These acts discredit Justice, undermine the rule of law and do not benefit the Macau Special Administrative Region"103.

\footnotetext{
101 Article 217 Criminal Procedure Code of Macau (emphasis added).

102 See Article 205 Criminal Procedure Code of Macau.

${ }^{103}$ Unusually, the composition of the court in this second case did not include any Chinese judge. The three judges delivering the decision were all Portuguese nationals.
} 
The clash between the highest judiciary authorities of the Macau SAR is instructive. On the one side, the Macau CFA, emphasizing the rule of law, fundamental procedural rights and judicial supremacy, i.e. Macau's 'second' system. Indeed, the legal values underlying the decision of the court surely merit respect, but the ultimate result of such stance the Macau SAR may surrender fugitives to the whole world, except to Mainland China and Hong Kong - is difficult to stomach. On the other side, the prosecutorial authorities, highlighting a view that gives prevalence to the need to cooperate with the Mainland in the fight against crime and, possibly, a prevalence of politics over law ${ }^{104}$. The need to effectively deal with criminality within "one country" surely also deserves respect, but a surrender decided by the prosecutorial/police authorities, without any substantive and procedural guarantees afforded to the person under arrest, is similarly hard to stomach.

\section{ConcLusion}

While third options were available ${ }^{105}$, what is more important to highlight in the conclusion of this Article is that this high level 'judiciary clash' is nothing but one extreme example of the difficulties, tensions or frictions inherent in attempts to find the proper operation of "one country, two systems", an ingenious principle and idea and a multidimensional concept, which different layers, after two decades of implementation, are still unfolding.

\footnotetext{
${ }^{104}$ On law and international law as an instrument of politics in China, see CHIU, Hungdah, Communist China's Attitude Toward International Law, The American Journal of International Law, Vol. 60, No. 2 (Apr., 1966), p. 246-257. See also HUALING, Fu, XIAOBO Zhai, What makes the Chinese Constitution socialist?, International Journal of Constitutional Law, Volume 16, Issue 2, (15 June 2018), on what makes the PRC constitution a socialist constitution and the still, at present, dire state of constitutionalism in the Mainland.

105 See LEMOS, Miguel, Direitos Fundamentais e Processo Penal: o Habeas Corpus cit., p.264-267, arguing that the general provisions of Criminal Procedure Code of Macau provided sufficient grounds for the arrest of any fugitive searched through the Interpol system and that an analogical use of the provisions on arrest and surrender of Law 6/2006 might provide sufficient $a$ fortiori grounds for the arrest and surrender of a fugitive to Mainland China.
} 
Eleventh hour information: in what might possibly be a curious twist to this Article, and its reliance on the absence of Mainland-SARs agreements on this issue, a new unfolding event is taking place as we wrap up. Energized by the impossibility of extraditing to Taiwan a Hong Kong resident suspect of having killed his girlfriend in Taiwan ${ }^{106}$, the Government of Hong Kong introduced a bill to the Legislative Council providing for the possibility of surrendering fugitives to Taiwan, the Mainland and Macau. If the bill passes, a new layer will be added to "one country, two systems" that might constitute a decisive step marking future cooperation on surrender of fugitives within "one country" for decades to come.

\section{REFERENCES}

BIAGI, Francesco, FROSINI, Justin O. and MAZZONE, Jason (eds.), Constitutional History: Comparative Perspectives (Brill forthcoming 2019).

BINGZHI, Zhao. Estudo dobre a questão da cooperação judiciária em matéria penal entre o interior da China e as Regiões Administrativas Especiais de Hong Kong e de Macau. Revista Jurídica de Macau, Macau, número especial, p. 74-80, 2004.

BRABYN, Janice "Extradition and the SARs After Reunification", Macau Law Journal, 2002, p. 82-86.

BRABYN, Janice. Extradition and the Hong Kong Special Administrative Region. Case Western Reserve Journal of International Law, Ohio, vol. 20, issue 1, p. 169194, 1988.

BRABYN, Janice. Inter-Jurisdictional Co-operation in Criminal Matters: Extradition, Mutual Legal Assistance, Prisoner Transfer to and from the HKSAR. In: WACKS, Raymond(ed). The New Legal Order in Hong Kong. Hong Kong: Hong Kong University Press, 1999.

106 Taiwan (in Portuguese, also known as Ilha Formosa) is, according to the official position of the PRC, a part of China. It currently works as a small de facto country that it is not recognized as such by the overwhelming majority of the international community. It lies off the coast of the Fujian province of the PRC. 
CANOTILHO, José J. Gomes. As Palavras e os Homens, reflexões sobre a Declaração Conjunta Luso-Chinesa e a institucionalização do recurso de amparo de direitos e liberdades na ordem jurídica de Macau”, Revista Jurídica de Macau, número especial sobre O Direito de Amparo em Macau e no Direito Comparado, 1999, p. 11

CHAN, JMM. Why the Court of Final Appeal Was Wrong: Comments of the Mainland Scholars on the Judgment of the Court of Final Appeal. In: CHAN, J.M.M.; FU, H.; GHAI, Y. P. (eds.). Hong Kong's Constitutional Debate, Conflict over Interpretation. Hong Kong: Hong Kong University Press, 2000.

CHAN, Johannes. From Colony to Special Administrative Region. In: CHAN, Johannes. LIM, CL (eds) Law of the Hong Kong Constitution. Hong Kong: Sweet \& Maxwell, 2015.

CHIU, Hungdah. Communist China's Attitude Toward International Law. The American Journal of International Law, Washington, vol. 60, issue 2, p. 246-257, 1966. https://doi.org/10.2307/2197572

COSTA, Miguel João. Dedere aut judicare? A decisão de extraditar ou julgar à luz do direito português, europeu e internacional. Coimbra: Instituto Jurídico da Faculdade de Direito da Universidade de Coimbra, 2014.

CULLEN, Richard. FU, H.L. Some Limitations in the Basic Law Exposed. China Perspectives, vol. 22, p. 54-57, 1999.

DAVIS, Michael C. Interpreting Constitutionalism and Democratization in Hong Kong. In: FU, Hualing; HARRIS, Lison; YOUNG, Simon N.M. (eds.). Interpreting Hong Kong's Basic Law: The Struggle For Coherence. New York: Palgrave Macmillan, 2007.

DIAS, Jorge de Figueiredo, Algumas questões em tema de extradição e de sede do crime [anotação], Revista de Legislação e Jurisprudência,118 (1985).

FERREIRA, Ilda Cristina, The Surrender of Fugitives offenders in Macao SAR, 2016, p. 307, 308.

FU, H L. Supremacy of a Different Kind: The Constitution, the NPC, and the Hong Kong SAR. In: CHAN, Johannes M.; FU, H. L.; GHAI, Yash. (eds) Hong Kong's Constitutional Debate. Conflict over Interpretation. Hong Kong: Hong Kong University Press, 2000. 
GITTINGS, Danny. Introduction to the Basic Law. Hong Kong: Hong Kong University Press, 2013.

GITTINGS, Danny. Introduction to the Basic Law. Second Edition. Hong Kong: Hong Kong University Press, 2016.

GUOQIANG, Zhao, Auxílio judiciário mútuo inter-regional na China sob as condições de 'um país, dois sistemas', Revista Jurídica de Macau, No Especial, 2004, p. 105-109.

HUALING, Fu. XIAOBO, Zhai. What makes the Chinese Constitution socialist? International Journal of Constitutional Law, Oxford, v. 16, issue 2, p. 655-663, 2018. https://doi.org/10.1093/icon/moy016

KIELSGARD, Mark D. IP, Ken Gee-Kin. Hong Kong's Failure To Extradite Edward Snowden: More Than Just A Technical Defect. Richmond Journal of Global Law \& Business, Richmond, vol. 13, issue 1, p. 49-66, 2014.

LEE, Martin. A Tale of Two Articles. In: WESLEY-SMITH, Peter. CHEN, Albert H. Y. (eds.) The Basic Law and Hong Kong's Future. Hong Kong: Butterworths, 1988.

LEMOS, Miguel Manero. Os “crimes incaucionáveis” no Código de Processo Penal de Macau. In: COSTA, José de Faria; et. al. Estudos em Homenagem ao prof. Doutor Manuel da Costa Andrade. Volume II. Coimbra: Studia Iuridica, 2017.

LEMOS, Miguel, Direitos Fundamentais e Processo Penal: o Habeas Corpus, o Direito ao Recurso de Decisão Condenatória e as Funções de Tutela de Direitos Fundamentais do Tribunal de Instrução Criminal, Segundas Jornadas de Direito e Cidadania da Assembleia Legislativa da RAEM, Direitos Fundamentais - Consolidação e Perspectivas de Evolução, Coord. Leonel Alves e Paulo Cardinal, 2016, p. 257-267.

LIM, C.L., MUSHKAT, R., External Affairs, in CHAN, J.M.M. Chan \& LIM, C.L. (eds), Law of the Hong Kong Constitution, 2nd ed. Hong Kong: Sweet \& Maxwell, 2015.

LO, Shiu Hing. The Politics of Cross-Border Crime in Greater China: Case Studies of Mainland China, Hong Kong, and Macao. Pacific Affairs, Vancouver, vol. 83, n. 03 , p. 587-589, 2010.

MACARTNEY, Jane (21 January 2010), "Chinese democracy leader Zhou Yongjun jailed for fraud", The Times. 
OLIVEIRA, Jorge Costa. Macau SAR Inter-Regional Mutual Legal Assistance in Criminal Matters. Oliveira J.C., Cardinal P. (eds) One Country, Two Systems, Three Legal Orders - Perspectives of Evolution. Berlin: Springer, 2009. https:// doi.org/10.1007/978-3-540-68572-2_34

PEREIRA, Francisco Gonçalves. Portugal, a China e a "Questão de Macau”. The China Quarterly, Cambrigde, v. 156, p. 1047-1049, 1998. https://doi.org/10.1017/ S0305741000051481

TAI, Benny. The Judiciary. In: WAI-MAN, Lam; LUI, Percy L; WONG, Wilson (eds). Contemporary Hong Kong Government and Politics. Expanded Second Edition. Hong Kong: Hong Kong University Press, 2012.

WAN, Choy Dick. Prisoner Transfer between Hong Kong and Mainland China: A Preliminary Assessment. Brooklyn Journal of International Law, Brooklyn, v. 33, issue 2, p. 463-501, 2008.

WANG, Dong. China's Unequal Treaties: Narrating National History. OXFORD: Lexington Books, 2005.

YEE, Marsha Wellknown. Hong Kong's legal obligation to require fair trial for rendition. Columbia Law Review, New York, vol. 102, n 5, p. 1373-1412, 2002. 


\section{Informações adicionais e declarações dos autores (integridade científica)}

Agradecimentos (acknowledgement): The authors would like to thank Calla Chau for suggestions and help in reviewing the text. Thanks is also due to Simon Young for his acute remarks and to the reviewers and editors, particularly Pedro Caeiro, whose comments and suggestions were always right on spot.

Declaração de conflito de interesses (conflict of interest declaration): os autores confirmam que não há conflitos de interesse na realização das pesquisas expostas e na redação deste artigo.

Declaração de autoria e especificação das contribuições (declaration of authorship): todas e somente as pessoas que atendem os requisitos de autoria deste artigo estão listadas como autores; todos os coautores se responsabilizam integralmente por este trabalho em sua totalidade.

- Miguel Manero de Lemos: projeto e esboço inicial, coleta e análise de dados, levantamento bibliográfico, revisão bibliográfica, redação, aprovação da versão final.

- Teresa Lancry Robalo: coleta e análise de dados, levantamento bibliográfico, revisão bibliográfica, redação, aprovação da versão final.

Declaração de ineditismo e originalidade (declaration of originality): os autores asseguram que o texto aqui publicado não foi divulgado anteriormente em outro meio e que futura republicação somente se realizará com a indicação expressa da referência desta publicação original; também atestam que não há plágio de terceiros ou autoplágio. 
Dados do processo editorial

(http://www.ibraspp.com.br/revista/index.php/RBDPP/about/editorialPolicies)

- Recebido em: 10/04/2019

Equipe editorial envolvida

- Controle preliminar e verificação de plágio:

- Editor-chefe: 1 (VGV) 11/04/2019

- Avaliação 1: 22/04/2019

- Avaliação 2: 12/04/2019

- Avaliação 3: 14/04/2019

- Editor-associado: 1 (PC)

- Editor-assistente: 1 (CRG)

- Revisores: 3

- Decisão editorial preliminar: 15/05/2019

- Retorno rodada de correções: 25/05/2019

- Decisão editorial final: 04/06/2019

\section{COMO CITAR ESTE ARTIGO:}

LEMOS, Miguel M.; ROBALO, Teresa L. Judicial cooperation in criminal matters in the Special Administrative Regions of Hong Kong and Macau. Through the lens of "one country, two systems" and the surrender of fugitives to Mainland China. Revista Brasileira de Direito Processual Penal, Porto Alegre, vol. 5, n. 2, p. 737-772, mai./ago. 2019. https://doi.org/10.22197/rbdpp.v5i2.242

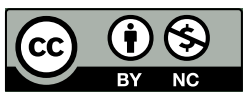

Esta obra está licenciada com uma Licença Creative Commons Atribuição-NãoComercial 4.0 Internacional. 